\title{
Light driven lipid peroxidation of coral membranes and a suggested role in calcification
}

\author{
I.M. Sandeman \\ Dept of Biology, Trent University, Peterborough, Ontario, K0L 2H0, Canada; isandem@pipcom.com
}

Received 13-VII-2007. C Corrected 15-XI-2007. Accepted 13-II-2008.

\begin{abstract}
Low concentrations of calcium ions $\left(\mathrm{Ca}^{2+}\right)$ are maintained in living cells by the Ca-ATPase calcium pump of the plasma membrane. The presence of a calcium pump in corals has been confirmed and its temperature related breakdown underlies coral bleaching. There is also mounting evidence from stable calcium isotope ratios in the skeleton for involvement of a calcium pump in coral calcification. Hydrogen peroxide $\left(\mathrm{H}_{2} \mathrm{O}_{2}\right)$ is known to be generated by zooxanthellae during photosynthesis and passes easily through cell membranes. $\mathrm{H}_{2} \mathrm{O}_{2}$ is known to cause lipid peroxidation of the plasma membrane and make it leaky to $\mathrm{Ca}^{2+}$. In this study lipid peroxidation was measured in the tissues of Agaricia agaricites. Lipid peroxides in the light doubled from 5.83 to $\left.11.23 \mu{\mathrm{Mol} . \mathrm{cm}^{-2}}^{-2} \mathrm{n}=17\right)$ over the first 3-4 hours then slowly decreased over the next four hours. Glutathione, which in many organisms acts as a lipid peroxidation repair system, was also found at a mean level of $79 \mu \mathrm{g} . \mathrm{cm}^{-2}$ $(n=14)$ and probably accounts for the observed reduction of lipid peroxide levels. It is suggested that the lipid peroxidation makes the plasma membrane leaky to $\mathrm{Ca}^{2+}$ and thus provides a route by which $\mathrm{Ca}^{2+}$ enters cells of the calicoblastic layer. A model of calcification, following Adkins et al. (2003), is presented in which calcification takes place from the extracellular calcifying fluid (ECF) between the calicoblastic layer and the skeleton. The Ca-ATPase calcium pump drives calcification by actively transporting $\mathrm{Ca}^{2+}$ into the ECF and setting up $\mathrm{pH}$ and carbon dioxide $\left(\mathrm{CO}_{2}\right)$ gradients that enhance the passive diffusion of $\mathrm{CO}_{2}$ and the formation of calcium carbonate. It is suggested that, in light, $\mathrm{H}_{2} \mathrm{O}_{2}$ produced by zooxanthellae makes the membranes leaky to $\mathrm{Ca}^{2+}$. The calcium pump has to work harder to maintain low internal levels of calcium and thus more $\mathrm{Ca}^{2+}$ would be actively transported into the ECF to be deposited as calcium carbonate. Rev. Biol. Trop. 56 (Suppl. 1): 1-9. Epub 2008 May 30.
\end{abstract}

Key words: coral calcification, Ca-ATPase calcium pump, hydrogen peroxide, lipid peroxidation.

Calcium carbonate is generally saturated in seawater but the mechanism by which it is laid down in the skeleton of scleratinian corals is not completely understood. Calcification takes place from the extracellular calcifying fluid (ECF) in the space between the skeleton and the coral's calicoblastic membrane (McConnaughey 1989, Adkins et al. 2003). Carbon dioxide, either metabolic in origin or from seawater, is able to diffuse from the calicoblastic layer into the ECF to provide a source for carbonate. Charged calcium ions $\left(\mathrm{Ca}^{2+}\right)$, to which membranes are impermeable, would have to be actively transported into the
ECF using Ca-ATPase calcium pump suggested by Chalker (1976) and demonstrated by Ip et al. (1991), travel by pericellular pathways (Cohen and McConnaughey 2003) or by leaking from the surrounding seawater as in an open system (Adkins et al. 2003). The latter alternative seems unlikely as Furla et al. (2000) estimated that $70-75 \%$ of the carbon was metabolic in origin and corals produce six times the amount of $\mathrm{CO}_{2}$ that is used for calcification. Tambutté et al. (1996) confirmed an intracellular pathway for $\mathrm{Ca}^{2+}$ transportation in corals and suggested that two types of cells were involved: $\mathrm{Ca}^{2+}$ transporting cells using L-type 
voltage dependent $\mathrm{Ca}^{2+}$ channels with an energy consuming mechanism and cells with $\mathrm{Ca}^{2+}$ channels that permitted passive movement of $\mathrm{Ca}^{2+}$. The involvement of voltage dependent $\mathrm{Ca}^{2+}$ channels is supported by molecular evidence (Zoccola et al. 1999). The operation of Ca-ATPase calcium pump/proton pump $\left(\mathrm{Ca}^{2+}\right.$ out and $\mathrm{H}^{+}$in) ( Al-Horani et al. 2003 and Zoccola et al. 2004) acts as an alkalinity pump and produces $\mathrm{pCO}_{2}$ and $\mathrm{pH}$ gradients which enhance the passive diffusion of $\mathrm{CO}_{2}$ into the ECF, driving the series of equations to the right, thus enhancing calcification.

$$
\begin{gathered}
\mathrm{H}_{2} \mathrm{O}+\mathrm{CO}_{2} \rightarrow \mathrm{H}^{+} \boldsymbol{\varphi}+\mathrm{HCO}_{3}{ }^{\prime} \\
\mathrm{HCO}_{3}{ }^{\prime} \rightarrow \mathrm{H}^{+} \boldsymbol{\uparrow}+\mathrm{CO}_{3} ” \\
\mathrm{CO}_{3}+\downarrow \mathrm{Ca}^{2+} \rightarrow \mathrm{CaCO}_{3} \downarrow
\end{gathered}
$$

(Note: $\mathrm{CO}_{2}$ and $\mathrm{H}_{2} \mathrm{O}$ enter the ECF by diffusion, $\mathrm{Ca}^{2+}$ is pumped in $(\downarrow), \mathrm{H}^{+}$out $(\mathbf{4})$, and $\mathrm{CaCO}_{3}$ is deposited ( $\left.\downarrow\right)$.

How $\mathrm{Ca}^{2+}$ enters the calicoblastic layer is not clear. Goreau (1959) demonstrated a large, exchangeable pool in the coelenteron which may be exchanged with seawater from the outside mainly at night and a smaller pool in the tissue. Channels through which calcium can be selectively taken up were suggested by Clode and Marshall (2002). $\mathrm{Ca}^{2+}$ channels permitting the uptake of $\mathrm{Ca}^{2+}$ by the calicoblastic and oral epidermal cells (Zoccola et al. 1999) and $\mathrm{Ca}^{2+}$ uptake involving special cells (Tambutté et al. 1996) have been suggested. Intracellular $\mathrm{Ca}^{2+}$ transport may be achieved by $\mathrm{Ca}^{2+}$ binding proteins or diffusion, but not by intracellular vesicles (Bohm et al. 2006). The organic matrix on which calcium carbonate is deposited has been shown by Tambutté et al. (2006) to consist of structural proteins which also play a catalytic role by eliminating the kinetic barrier to inter-conversion of inorganic carbon. Fractionation of the stable isotopes of calcium is to be expected if an ATPase calcium/proton pump is involved in actively transporting calcium ions into the ECF. However the results of stable isotope analysis of coral skeletons have proved somewhat ambiguous (Bohm et al.
2006). They found that scleratinian corals are enriched in $\delta^{44 / 40}$ Ca by 0.4-0.5 \%o compared to slowly deposited sclerosponge and inorganic aragonite but are lower than might be expected from their high deposition rates. The ${ }^{44} \mathrm{Ca} /$ ${ }^{40} \mathrm{Ca}$ ratios found by Gussone et al. (2005) and Bohm et al. (2006) were also positively correlated with temperature. Coral calcification rates are known to be higher in the light (Goreau 1959) and corals may, for example, calcify eleven times faster in light than in the dark (Erez 1978).

The Ca-ATPase pump of animal cell plasma membranes maintains low internal concentrations of $\mathrm{Ca}^{2+}$. The effect of light on intracellular $\mathrm{Ca}^{2+}$ is not known and studies on the effects of temperature on intracellular $\mathrm{Ca}^{2+}$ levels in isolated coral cells have given conflicting results. Sawyer and Muscatine (2001) found no significant changes in with heat or cold shock while Fang et al. (1997) and Huang et al. (1998) found increases proportionate to the duration of the heat treatment. Disruption of the calcium pump in intact corals by high temperature has been shown (Sandeman 2006) to lead to high internal cellular concentrations of $\mathrm{Ca}^{2+}$. This results in blebbing or ballooning out of the membrane and eventual fragmentation of the gastrodermal layer and loss of zooxanthellae (bleaching). The same end results are obtained at lower temperatures in light as the result of the accumulation of intracellular $\mathrm{H}_{2} \mathrm{O}_{2}$. That study showed that both isolated zooxanthellae and whole corals release hydrogen peroxide $\left(\mathrm{H}_{2} \mathrm{O}_{2}\right)$ during photosynthesis. At high temperatures $\mathrm{H}_{2} \mathrm{O}_{2}$ interferes with the calcium exclusion mechanisms, probably by combining with - $\mathrm{SH}$ groups, and leads to bleaching. At lower temperatures, and on a localized basis, $\mathrm{H}_{2} \mathrm{O}_{2}$ probably plays a part in the regulation of algal populations in the coral. $\mathrm{H}_{2} \mathrm{O}_{2}$ is produced directly during photosynthesis of the coral, or indirectly by the dismutation of the superoxide radical $\left(\mathrm{O}_{2}^{-}\right) \cdot \mathrm{H}_{2} \mathrm{O}_{2}$ is able to move easily through biological membranes and to cause lipid peroxidation (Halliwell and Gutteridge 1999). Neither $\mathrm{H}_{2} \mathrm{O}_{2}$ nor $\mathrm{O}_{2}^{-}$is sufficiently reactive on its own to initiate lipid 
peroxidation (Halliwell and Gutteridge 1999). However, when they occur together in the presence of iron or other transition metal ions, hydroxyl radicals $\left(\mathrm{OH}^{*}\right)$ can be produced by the Haber-Weiss reaction. Hydrogen peroxide and organic peroxides are also able to release iron ions from iron proteins and may also form hydroxyl radicals by Fenton chemistry. Hydroxyl radicals initiate lipid peroxidation in hydrocarbon side chains containing polyunsaturated fatty acids (PUFAs) by abstracting $\mathrm{H}$ and if oxygen is present peroxyl radicals are formed which are capable of extracting $\mathrm{H}$ from other PUFAs to form more lipid peroxides and a chain reaction results. Thus a few hydroxyl radicals may lead to considerable lipid peroxidation in the absence of glutathione (GSH) to repair and minimize damage. In the repair process GSH is oxidized to GSSG. Glutathione reductase catalyses the reduction of GSSG back to GSH but requires NADPH. Lipid peroxidation makes cell membranes leaky to $\mathrm{Ca}^{2+}$ (Halliwell and Gutteridge 1999) and provides a possible route for $\mathrm{Ca}^{2+}$ to enter cells. With leakage taking place the calcium pump would have to work harder to maintain the low internal concentration of $\mathrm{Ca}^{2+}$. For cells of the calicoblastic layer, during daylight hours, more of the leaked $\mathrm{Ca}^{2+}$ would be transported out into the EFC where it would be deposited as $\mathrm{CaCO}_{3}$. This mechanism would explain the higher coral calcification rates for daylight than those found at night (Goreau 1959) and may explain the higher calcification rates of hermatypic as compared to ahermatypic and deep-sea corals.

The aim of this study was to determine whether lipid peroxidation takes place in corals and to detect the expected presence of a repair system involving glutathione. These would give support to the role suggested above for $\mathrm{H}_{2} \mathrm{O}_{2}$ in coral calcification.

\section{MATERIALS AND METHODS}

\section{Coral sampling and preparation:}

All sea water used for experiments was passed through a column of 4-8 mesh activated charcoal (Sigma) and millepore-filtered $(0.45 \mu)$.
Small pieces of live coral, Agaricia agaricites, were collected in the back reef at Discovery Bay, Jamaica and were held in the sea water table at the Discovery Bay Marine Laboratory of the University of the West Indies. Small platelike Agaricia colonies with a thin outer edge proved to be a particularly useful source of material as the structure was simple, consisting of parallel septa, and pieces could be easily trimmed to a desired shape with small scissors. Small pieces from the edge of colonies of Montastrea faveolata were obtained and subdivided with a hammer and chisel. The area of pieces of coral used for experiments was estimated with aluminium foil (Marsh 1970). The sea water table and the laboratory in which the experiments were carried out both had low illumination $\left(<5 \mu \mathrm{mol} \cdot \mathrm{m}^{-2} \cdot \mathrm{s}^{-1}\right)$.

Lipid peroxidation: The production of lipid peroxide was estimated with the Fox2 technique (Jiang et al. 1991, Wolff 1994). Nine small pieces (approx $2 \mathrm{~cm}^{2}$ each) from the same colony were used in each experiment. One piece was analysed at the start of the experiment (dark result), four of the remainder were placed in each of two small vessels of seawater, one held at $28^{\circ} \mathrm{C}$, the other at $33^{\circ} \mathrm{C}$ in constant temperature baths. Irradiation $\left(800 \mu \mathrm{mol} . \mathrm{m}^{-2} . \mathrm{s}^{-1}\right.$ measured with a model LI-250, LI-COR Quantum Radiometer) was provided by 60 -watt halogen spotlights with heat filters and 80b optical filters. Pieces of coral were withdrawn at intervals of two hours for analysis. Each piece of coral was water-piked with millipore-filtered seawater which was then homogenised briefly to break up the mucus and centrifuged at low speed for four minutes to deposit the zooxanthellae. The supernatant fluid with suspended animal tissue, was drawn through a glass-fiber filter which retained the solid material. The filter was rinsed with distilled water to remove salt and extracted in a $15 \mathrm{ml}$ centrifuge tube with $10 \mathrm{ml}$ of Fox2 reagent (final concentrations: $100 \mu \mathrm{M}$ xylenol orange, $250 \mu \mathrm{M}$ ammonium ferrous sulphate, $90 \%$ methanol, $4 \mathrm{mM}$ butylated hydroxytoluene and $25 \mathrm{mM} \mathrm{H}_{2} \mathrm{SO}_{4}$ ). 
After centrifuging to remove suspended solids and standing for 30 minutes the absorbance of a two $\mathrm{ml}$ sub-sample was read at $560 \mathrm{~nm}$ in a spectrophotometer. Known concentrations of hydrogen peroxide were used to calibrate the analysis and results were corrected for the area of each piece of coral. Absorbances continued to increase slowly after 30 minutes at room temperature indicating that some chain oxidation, not inhibited by the butylated hydroxy toluene, might be taking place. A small portion ( $<5 \%$ ) of the absorbance at $560 \mathrm{~nm}$ could be attributed to pigments in the few zooxanthellae that were not removed by centrifugation, this was ignored. Statistical procedures were carried out with NCSS 2000 statistical software (Dr Jerry L. Hintze, Kaysville, Utah 84037).

Glutathione: Glutathione levels in the tissues of Agaricia, before and during exposure to high light/temperature, was estimated using a technique following Cohn and Lyle (1966), McNeil and Beck (1968), and Hissin and Hilf (1976). This technique is based on the reaction of reduced glutathione (GSH) with $o$-phthalaldehyde (OPT) at $\mathrm{pH} 8$ to give a fluorescent compound (emission at $425 \mathrm{~nm}$ ). McNeil and Beck (1968) reported that with higher concentrations of extract a yellow quenching compound develops with the addition of OPT. This reaction was taking place with the coral extracts and, to minimise its effect, higher concentrations of OPT were used to lessen the time over which fluorescence reached a plateau before it started dropping again. For each estimation of GSH the initial coral extract was divided into two parts. To one part a known quantity of GSH was added and the two samples were processed together identically. From the results the concentration of GSH was calculated and corrected for the area.

Small samples $\left(2-3 \mathrm{~cm}^{2}\right)$ from three Agaricia plates maintained in seawater at $32{ }^{\circ} \mathrm{C}$ and exposed to illumination of $350 \mu \mathrm{mol} . \mathrm{m}^{-2}$. $\sec ^{-1}$ were withdrawn for analysis at intervals of about three hours. Each was water-piked with approximately $10 \mathrm{ml}$ seawater which was then homogenized with a high-speed homogenizer (30 seconds) and centrifuged at low speed for three minutes to deposit the zooxanthellae. The supernatant was decanted, its volume recorded, and it was then divided into two parts, each of $4.5 \mathrm{ml}$. To one portion $0.1 \mathrm{ml}$ of buffer containing $100 \mu \mathrm{g}$ of GSH was added. To each part $0.25 \mathrm{ml}$ of concentrated phosphoric acid was added and mixed well with a vortex mixer to precipitate any protein present. After centrifugation at $5000 \mathrm{~g}$ for eight minutes, sodium hydroxide (pellets and a strong solution) was added to bring the $\mathrm{pH}$ of each to 8.0 as measured with a $\mathrm{pH}$ meter. After further centrifugation at $5000 \mathrm{~g}$ for 4 minutes, $1 \mathrm{ml}$ of supernatant of each was added to $4 \mathrm{ml}$ of $0.1 \mathrm{M}$ sodium phosphate buffer (pH8). To $0.7 \mathrm{ml}$ of these solutions in sample vials, 0.1 $\mathrm{ml}$ of OPT solution in methyl alcohol (containing $300 \mu \mathrm{g}$ OPT) was added. The fluorescence of the two vials was read with a fluorometer (Sandeman 2006) at one minute intervals until a plateau was reached after which the fluorescence decreased. The difference between the maximum values of fluorescence for the spiked and unspiked samples represents the fluorescence due to $100 \mu \mathrm{g}$ of glutathione.

\section{RESULTS}

Lipid peroxidation: Typical results from Fox2 assays of lipid peroxide of coral pieces initially in the dark and held in seawater at 25-28 ${ }^{\circ} \mathrm{C}$ and $33-35{ }^{\circ} \mathrm{C}$ in light can be seen in Figure 1. All show lipid peroxides increasing to a maximum for the first 3-4 hours, this is followed by a period of reduction or recovery, either relatively quickly (Fig. 1A, C), or more slowly (Fig 1B). The experiments were originally carried out at two temperatures and under strong light to explore whether lipid peroxidation played a part in bleaching. Many of the pieces of coral held at the higher temperature exhibited signs of bleaching by the end of the experimental period but lipid peroxidation (Fig. 2A) was not significantly different for coral pieces held at the two temperatures. For the samples of Agaricia the means of lipid peroxidation at the start (dark) and after four hours 
A Agaricia, Lipid peroxides vs Time

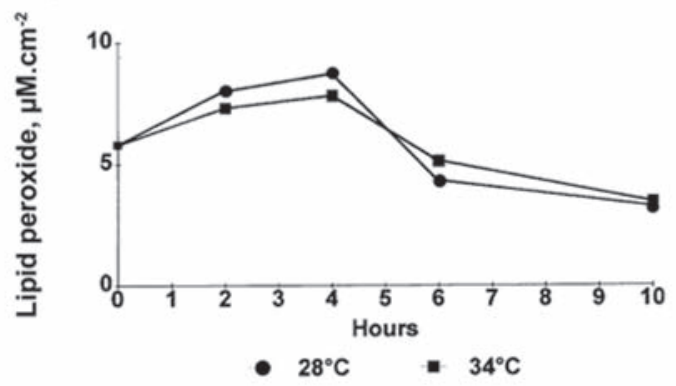

B

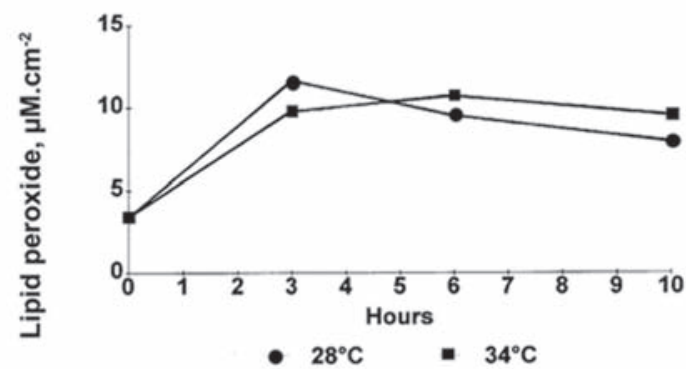

C

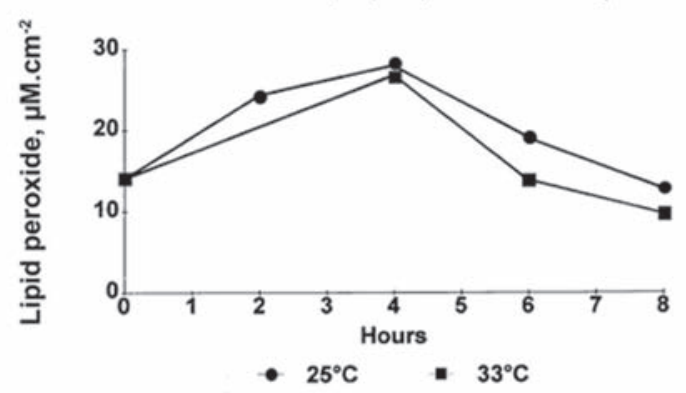

D Agaricia, Lipid peroxides vs Time Light/Dark

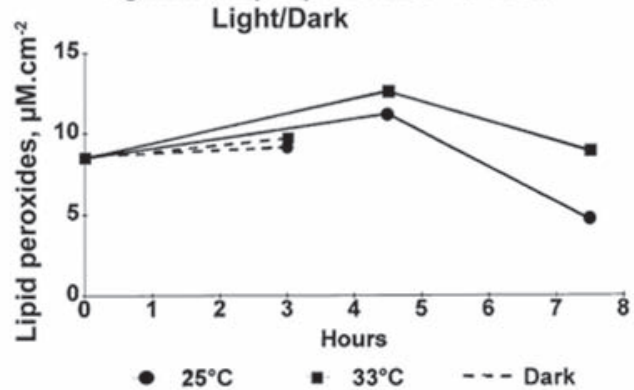

E
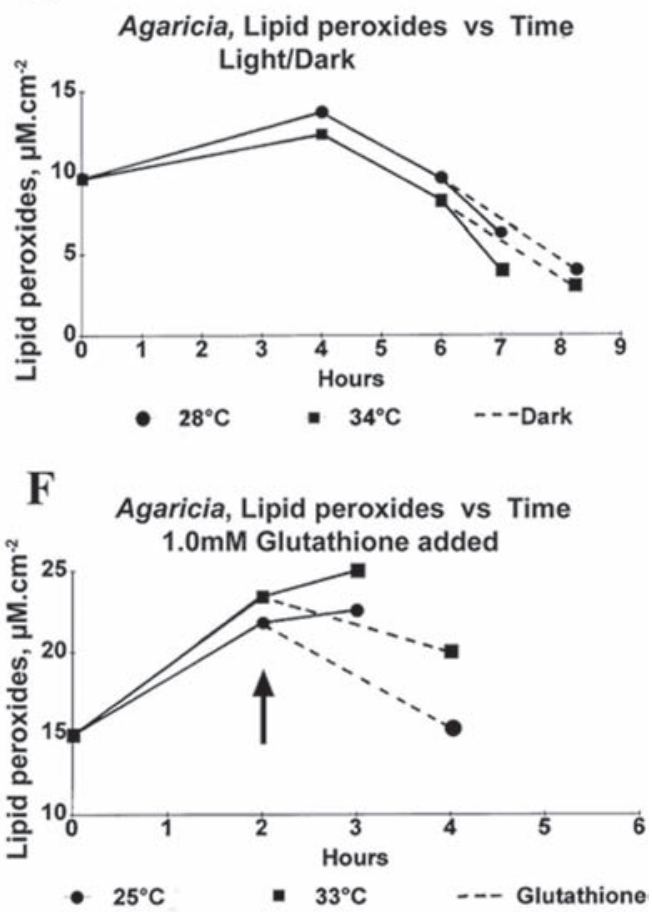

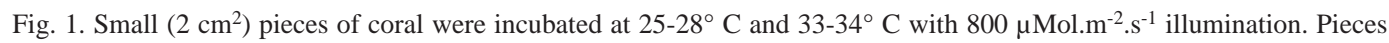
were removed at intervals and lipid peroxides were measured with the Fox2 technique. Lipid peroxides are plotted against time. A,B Agaricia agaricites. C. Montastrea faveolata. D. Agaricia agaricites, two pieces held in the dark. E. Agaricia agaricites, two pieces held in the light during repair phase. F. Agaricia agaricites, pieces with $1.0 \mathrm{mM}$ glutathione added (arrow).

in light were significantly different $(\mathrm{p}=.0 .0033)$ for both temperatures. When the results for the two temperatures were combined together (Fig. 2B) the means of lipid peroxidation at the start (dark) and after four hours in the light were significantly different $(\mathrm{p}=0.0033)$. Pieces of coral $(\mathrm{n}=4)$ were simultaneously kept in the dark and light (an example in Fig. 1D) there was little change in lipid peroxide from the initial level. When coral pieces $(n=2)$ were held in the dark the rate of recovery was lower than that of the pieces held in the light (Fig. 1E). The addition $(\mathrm{n}=2)$ after two hours in the light, of $0.1 \mathrm{M}$ glutathione (GSH) to the seawater containing 


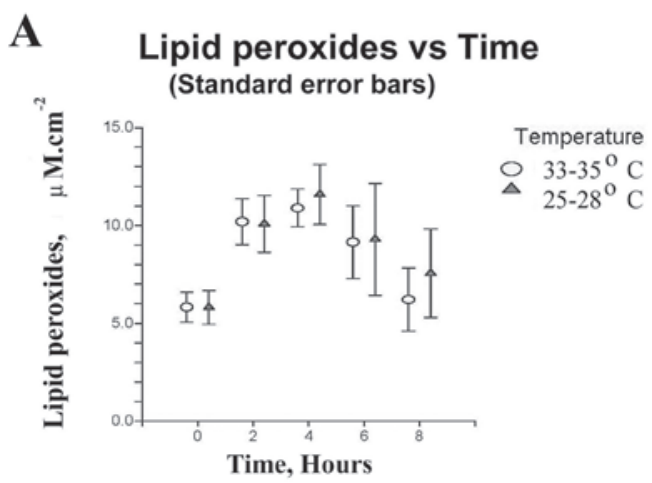

B

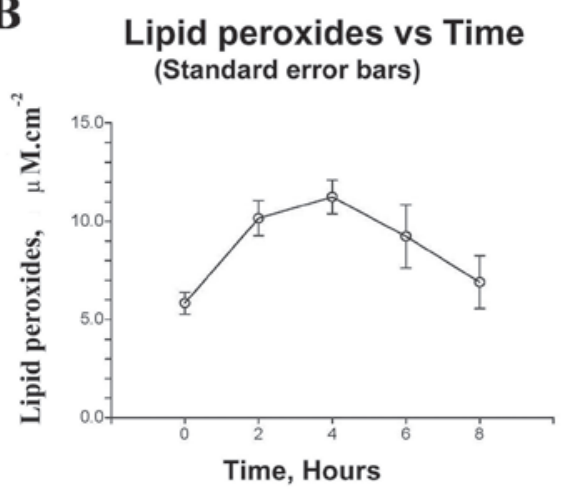

Fig. 2. Pieces of Agaricites agaricites incubated at $25-28^{\circ} \mathrm{C}$ and $33-34^{\circ} \mathrm{C}$ under illumination of $800 \mu \mathrm{Mol} . \mathrm{m}^{-2} . \mathrm{s}^{-1}$. Lipid peroxides are plotted against time. Standard error bars are shown. A. Results for the two temperatures compared. B. Means of all results $(n=17)$ combined.

the corals (Fig. 1F), reversed the increase in lipid peroxide to a fairly rapid reduction. The combined results from all experiments (Fig. 2B) indicate that the mean lipid peroxides level (initially $5.83 \mu \mathrm{M} . \mathrm{cm}^{-2}, \mathrm{n}=8$ ) increased during the first 3-4 hours in light to a maximum (11.23 $\left.\mu \mathrm{M} . \mathrm{cm}^{-2}, \mathrm{n}=17\right)$ then decreased to their original level. A single experiment with Montastrea faveolata (Fig. 1C) showed higher lipid peroxides levels but the pattern was similar to the results obtained for Agaricia agaricites.

Glutathione: Glutathione was present in all the samples analysed (mean $79.0 \mu \mathrm{g} / \mathrm{cm} 5$, $\mathrm{n}=11$ ). The results for the samples from the three colonies can be seen in Fig. 3. From the regression line and R5 value (0.00) for all the

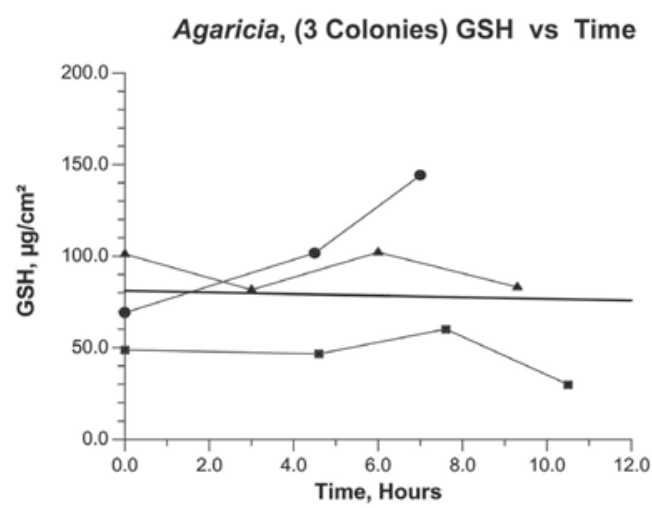

Fig. 3. Small (2-3 $\left.\mathrm{cm}^{2}\right)$ samples from three Agaricites agaricites colonies were incubated at $32^{\circ} \mathrm{C}$ with $350 \mu \mathrm{Mol}^{-\mathrm{M}^{-}}$ ${ }^{2} . \mathrm{s}^{-1}$ illumination. Samples were removed at intervals for estimates of GSH. GSH is plotted against time. Regression line is shown.

points, it is clear that there is no difference in glutathione level over the ten hour period during which the samples were exposed to light.

\section{DISCUSSION}

These experiments indicate that lipid peroxides in the tissues of Agaricia agaricites increase in the light to a maximum in 3-4 hours then decrease over the next few hours (Figs. 1, 2). Confirmation that similar patterns are found in other corals was provided by the experiment using $M$. faveolata. A possible explanation for the reduction in lipid peroxide is that a repair mechanism is involved, such as the GSHGSSG system that is commonly present in animals and is responsible for the repair of lipid peroxidation damage (Halliwell and Gutteridge 1999). The presence of GSH confirms that the same system is probably involved in corals. Further confirmation may come from the single experiment (Fig. 1F) in which lipid peroxidation was reversed and showed a high rate of repair when GSH was added to the seawater in which the coral was being held. Energy in the form of NADPH is required for the conversion of GSSG back to GSH (Halliwell and Gutteridge 1999). The higher recovery rate in 
the light seen in Fig. 1E might be explained if recovery is indirectly light driven. Levels of lipid peroxidation and the rates of formation and repair showed considerable variation. This probably results from the interplay of many factors: light and temperature levels, the rate of $\mathrm{H}_{2} \mathrm{O}_{2}$ production and loss, the rate at which hydroxyl ions are generated, the quantity of GSH present and the presence of glutathione reductase and NADPH to regenerate glutathione from oxidised glutathione.

Lipid peroxidation is known to make the plasma membrane leaky to calcium ions (Halliwell and Gutteridge 1999) and in view of the presence of GSH and the light related formation of lipid peroxides, this is very likely to be the case for corals. There is no direct evidence that intracellular $\mathrm{Ca}^{2+}$ increases in the light and information on the effect of temperature on intracellular $\mathrm{Ca}^{2+}$ is conflicting. However, $\mathrm{H}_{2} \mathrm{O}_{2}$, which can move easily through cell membranes and is the probable source of lipid peroxidation, was shown to accumulate in coral tissues in light (Sandeman 2006).

Calcium ions are charged and are unable to pass easily through the plasma membrane. Suggestions for how $\mathrm{Ca}^{2+}$ enters the calicoblastic layers include "special” channels (Zoccola et al. 1999, Clode and Marshall 2002) or special cells (Tambutté et al. 1996). During the day, when photosynthetic production of $\mathrm{H}_{2} \mathrm{O}_{2}$ is high, leakage due to lipid peroxidation thus provides, without invoking "special" channels or cells, a route for $\mathrm{Ca}^{2+}$ to enter the calicoblastic layer before being actively transported out and into the ECF by the calcium/proton pump (Fig. 4). The availability of $\mathrm{CO}_{2}$ in the calicoblastic layer is enhanced by the proton pump and $\mathrm{CO}_{2}$ diffusion into the ECF is also enhanced (Adkins et al. 2003). The series of reactions leading to the formation of $\mathrm{CO}_{3}$ " is enhanced by the removal of protons, $\mathrm{CO}_{3}$ " combines with $\mathrm{Ca}^{2+}$ and is deposited as calcium carbonate (Fig. 4). These reactions probably take place on

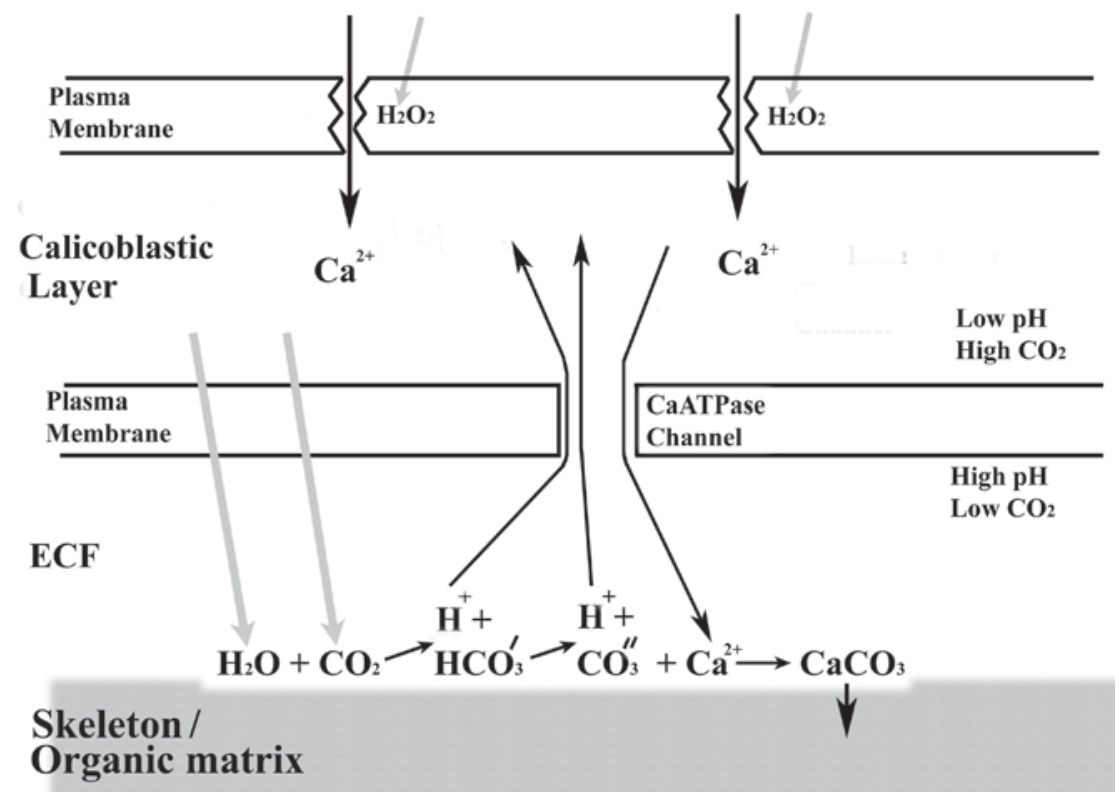

Fig. 4. A model of calcification (following Adkins et al. 2003). $\mathrm{CO}_{2}$ and water diffuse into the calicoblastic layer and ECF. In daylight $\mathrm{Ca}^{2+}$ enters the calicoblastic layer by leakage caused by lipid peroxidation of the plasma membrane by $\mathrm{H}_{2} \mathrm{O}_{2}$. The Ca-ATPase calcium pump actively transports $\mathrm{Ca}^{2+}$ into the ECF and protons out, setting up a $\mathrm{pH}$ gradient which enhances the diffusion of $\mathrm{CO}_{2}$. Removal of protons also enhances the conversion of $\mathrm{CO}_{2}$ to $\mathrm{CO}_{3}$ ” on the organic matrix. $\mathrm{CO}_{3}$ " combines with $\mathrm{Ca}^{2+}$ and is deposited as $\mathrm{CaCO}_{3}$. 
the surface of the protein organic matrix which has been shown to have the catalytic properties of carbonic anhydrase (Tambutté et al. 2007). At night and in azooxanthellate corals there is probably a basal rate at which $\mathrm{Ca}^{2+}$ leaks into the cells and is actively transported into the ECF by the calcium/proton pump. During the day in zooxanthellate corals $\mathrm{H}_{2} \mathrm{O}_{2}$ is produced, diffuses into the coelenteron and from there is distributed round the coral and can diffuse to the calicoblastic layer (Sandeman 2006). It causes lipid peroxidation of the plasma membranes which is likely to make them leaky to $\mathrm{Ca}^{2+}$. The calcium pump would have to work harder, resulting in more $\mathrm{Ca}^{2+}$ being actively transported into the ECF and resulting in higher calcification rates.

Hydrogen peroxide, generated directly by their symbionts or indirectly by the dismutation of superoxide, appears to play an important part in the life of corals. At low concentrations $\mathrm{H}_{2} \mathrm{O}_{2}$ may enhance calcification during daylight hours as described above. At intermediate levels it may provide a localized mechanism by which the numbers of zooxanthellae in the gastrodermis are regulated and at still higher levels it is involved in solar bleaching (Sandeman 2006).

\section{RESUMEN}

La bomba de calcio Ca-ATPase de la membrana de plasma mantiene bajas las concentraciones de iones de calcio $\left(\mathrm{Ca}^{2+}\right)$ en las células vivas. La presencia de una bomba de calcio en los corales ha sido confirmada, y su fallo en el funcionamiento debido al cambio de temperatura es lo que conlleva al blanqueamiento de coral. Existe también abundante evidencia obtenida de los proporciones de los isótopos estables del calcio en el esqueleto, de que hay una bomba de calcio involucrada en la calcificación del coral. Como se sabe, el peróxido de hidrógeno $\left(\mathrm{H}_{2} \mathrm{O}_{2}\right)$ es generado por las zooxantelas durante la fotosíntesis y pasa fácilmente a través de las membranas celulares. Además, el $\mathrm{H}_{2} \mathrm{O}_{2}$ produce la peroxidación de lípidos de la membrana plasmática y lo hace permeable al $\mathrm{Ca}^{2+}$. En el presente estudio, se midió la peroxidación lípida en los tejidos de Agaricia agaricites. Los peróxidos lípidos en la luz se duplicaban, de 5.83 a $11.23 \mu$ Mol.cm ${ }^{-2}(\mathrm{n}=17)$, durante las primeras 3 a 4 horas, y luego, disminuían lentamente durante las siguientes 4 horas. El glutatión, que en muchos organismos actúa como parte del sistema de reparo de la peroxidación de los lípidos, fue encontrado en niveles significativos, $79 \mu \mathrm{g} . \mathrm{cm}^{-2}$ ( $n=14$ ), e indica probablemente la reducción observada en los niveles de peróxido lípido. Se sugiere que la peroxidación de lípidos hace que la membrana de plasma permita la fuga de $\mathrm{Ca}^{2+}$, y por lo tanto, que el $\mathrm{Ca}^{2+}$ tenga una ruta para entrar en las células de la capa calcioblástica. El modelo de calcificación según Adkins et al. (2003), presenta cómo la calcificación se lleva a cabo entre el líquido calcificante extracellular (ECF: extracellular calfifying fluid), que está en la capa calcioblástica, y el esqueleto. La bomba de calcio Ca-ATPase dirige la calcificación en la medida en que transporta el $\mathrm{Ca}^{2+}$ al ECF y establece los gradientes de $\mathrm{pH}$ y dióxido de carbono $\left(\mathrm{CO}_{2}\right)$ que permiten la difusión pasiva del $\mathrm{CO}_{2}$ y la formación de carbonato de calcio. Se sugiere que, en la luz, el $\mathrm{H}_{2} \mathrm{O}_{2}$ producido por las zooxantelas hace que las membranas permitan la fuga de $\mathrm{Ca}^{2+}$. La bomba de calcio tiene que trabajar más para mantener bajos los niveles internos de calcio, y consecuentemente, más $\mathrm{Ca}^{2+}$ sería transportado activamente al ECF para ser depositado como carbonato de calcio.

Palabras clave: calcificación de coral, bomba de calcio Ca-ATPase, peróxido de hidrógeno, peroxidación de lípidos.

\section{REFERENCES}

Adkins, J.F., E.A. Boyle, W.B. Curry \& A. Lutringer. 2003. Stable isotopes in deep-sea corals and a new mechanism for "vital effects". Geochim. Cosmochim. Acta 67: 1129-1143.

Al-Horani, F.A., S.M. Al-Moghrabi \& D. De Beer. 2004. The mechanism of calcification and its relation to photosynthesis and respiration in the scleratinian coral Galaxea fascicularis. Marine Biol. 142: 419-426.

Böhm, F., N. Gussone, A. Eisenhauer, W-C Dullo, S. Reynaud \& A. Paytan. 2006. Calcium isotope fractionation in modern scleratinian corals. Geochim. Cosmochim. Acta 70: 4452-4462.

Chalker, B.E. 1976. Calcium transport during skeletogenesis in hermatypic corals. Comp. Biochem. Physiol. 54: 455-459.

Clode, P.L. \& A.T. Marshall 2002. Low temperature X-ray microanalysis of calcium in a scleratinian coral: Evidence of active transport mechanism. J. Exp. Biol. 205: 3543-3552.

Cohen, A. \& T.A. McConnaughey. 2003. Geochemical perspectives on coral mineralization. Rev. Min. Geochem. 54: 151-187. 
Cohn, V.H. \& J.A. Lyle. 1996. A fluorometric assay for glutathione. Anal. Biochem. 14: 494-540.

Erez, J. 1978. Vital effect on stable isotope-composition seen in foraminifera and coral skeletons. Nature 273: 199-202.

Fang, L.S., S.P. Huang \& K.L. Lin. 1997. High temperature induces the synthesis of heat-shock proteins and the elevation of intracellular calcium in the coral Acropora grandis. Coral Reefs 16: 127-131.

Furla, P., I. Galgani, I. Durand \& D. Allemand. 2000. Sources and mechanisms of inorganic carbon transport for coral calcification and photosynthesis. J. Exp. Biol. 203: 3445-3457.

Goreau, T.F. 1959. The physiology of skeleton formation in corals. I. A method for measuring the rate of calcium deposition by corals under different conditions. Biol. Bull. 116: 59-75.

Gussone, N., F. Bohm, A. Eisenhauer, M. Dietzel, A. Heuser, B.M.A. Teichert, J. Reitner, G. Wörheide \& W.-Chr. Dullo. 2005. Calcium isotope fractionation in calcite and aragonite. Geochim. Cosmochim. Acta 69: 4485-4494.

Halliwell, B. \& J.M.C. Gutteridge. 1999. Free Radicals in Biology and Medicine. (Third Edition) Oxford University Press, Oxford, England.

Hissin, P.J. \& R. Hilf. 1967. A fluorometric method for determination of oxidized and reduced glutathione in tissues. Anal. Biochem. 74: 214-226.

Huang, S.P, K.L. Lin \& L.S. Fang. 1998. The involvement of calcium in heat induced coral bleaching. Zool. Stud. 37: 89-92.

Ip, Y.K., A.L.L. Lim \& R.W.L. Lim. 1991. Some properties of calcium-activated adenosine triphosphatase from the hermatypic coral Galaxea fascicularis. Mar. Biol. 111: 191-197.

Jiang, Z-Y., AC.S. Woolard, \& S. Wolff. 1991. Lipid hydroperoxide measurement by oxidation of $\mathrm{Fe}^{2+}$ in the presence of xylenol orange. Comparison with the TBA assay and an iodometric method. Lipids 26: 853-856.
Marsh, J.A. 1970. Primary productivity of reef-building calcareous red algae. Ecology 51: 255-263.

McNeil, T.L. \& L.K. Beck. 1968. Fluorometric estimation of GSH-OPT. Anal. Biochem. 22: 431-444.

McConnaughey, T. $1989 .{ }^{13} \mathrm{C}$ and ${ }^{18} \mathrm{O}$ isotopic disequilibrium in biological carbonates: I Patterns. Geochim. Cosmochim. Acta 53: 151-162.

Sandeman, I.M. 2006. Fragmentation of the gastrodermis and detachment of zooxanthellae in symbiotic cnidarians: a role for hydrogen peroxide and $\mathrm{Ca}^{2+}$ in coral bleaching and algal density control. Rev. Biol. Trop. 54 (Suppl. 3): 79-96.

Sawyer, S.T. \& L. Muscatine. 2001. Cellular mechanisms underlying temperature-induced bleaching in the sea anemone Aiptasia pulchella . J. Exp. Biol. 204: 3443-3456

Tambutté, E, D. Allemand, E. Mueller and J. Jaubert. 1996. A compartmental approach to the mechanism of calcification in hermatypic corals. J. Exp. Biol. 199: 1029-1041.

Tambutté, S., E. Tambutté. D. Zoccola, N. Camaniti, S. Lotto, A. Moya, D. Allemand \& J. Adkins. 2007. Characterization and role of carbonic anhydrase in the calcification process of the azooxanthellate coral Tubastrea aurea. Mar. Biol.151: 71-83.

Wolff, S.P. 1994. Ferrous ion oxidation in presence of ferric ion indicator xylenol orange for measurement of hydroperoxides. Meth. Enzym. 233: 182-189.

Zoccola, D., E. Tambutté, F. Senegar-Balar, J.F. Michiele, J.P. Faille, J. Jaubert \& D. Allemand. 1999. Cloning of a calcium channel $\alpha 1$ subunit from the reef-building coral Stylophora pistillata. Gene 227:157-167

Zoccola, D., E. Tambutté, E. Kulhanek, S. Puveral, J.-C. Scimeca, D. Allemand \& S. Tambutté 2004. Molecular cloning and localization of a PMCA P-type calcium ATPase from the coral Stylopora pistillata. Biochim. Biophys. Acta 1663: 117-126. 
